DOE/RL-96-19

Rev. 0

Mitigation Action Plan for Liquid Waste Sites in the 100-BC-1,

100-DR-1, and

100-HR-1 Operable Units

United States
Department of Energy 
TRADEMARK DISCLAIMER

Reference herein to any specific commercial product, process, or service by trade name, trademark, manufacturer, or otherwise. does not necessarily constitute or imply its endorsement, recommendation, or favoring by the United States Government or any agency thereof or its contractors or subcontractors.

This report has been reproduced from the best available copy. Available in paper copy and microfiche.

Available to the U.S. Department of Energy

and its contractors from

Office of Scientific and Technical Information

P.O. Box 62

Oak Ridge. TN 37831

(615) $576-8401$

Available to the public from the U.S. Department of Commerce National Technical Information Service

5285 Port Royal Road

Springfield, VA 22161

(703) 487.4650

Printed in the United States of America

DISCLM-5.CHP (8-91) 
DOE/RL-96-19

Rev. 0

\section{Mitigation Action Plan for Liquid Waste Sites in the 100-BC-1, 100-DR-1, and 100-HR-1 Operable Units}




\section{DISCLAIMER}

Portions of this document may be illegible in electronic image products. Images are produced from the best available original document. 
DOE/RL-96-19

REV: 0

OU: $\quad 100-B C-1,100-D R-1$, 100-HR-1

TSD: N/A

ERA: N/A

APPROVAL PAGE

Title of Document: $\quad$ MITIGATION ACTION PLAN FOR LIQUID WASTE SITES IN THE 100-BC-1, 100-DR-1, AND 100-HR-1 OPERABLE UNITS

Author(s): $\quad$ S. G. Weiss

Approval: $\quad$ Alvin Langstaff, Project Engineer

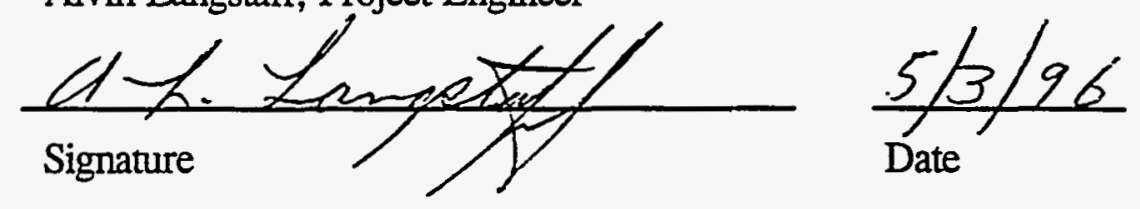

The approval signatures on this page indicate that this document has been authorized for information release to the public through appropriate channels. No other forms or signatures are required to document this information release. -

BHI-DIS 5-13-96 mA 
TO: Document \& Information Services

FROM: Glenn Van Sickle

SUBJECT: Distribution request for documents which are "For Information Only"

DATE: $5 / 8 / 96$

DOCUMENT Number: DOE/RL $-96-19$

DOCUMENT Revision: $\operatorname{Rev} 0$

The attached document is for INFORMATION QNLY. The document is NOT considered a deliverable, primary or secondary document and does not require review and comment by DOE or the regulators. Distribution is to be completed per the enclosed distribution, including DOE.

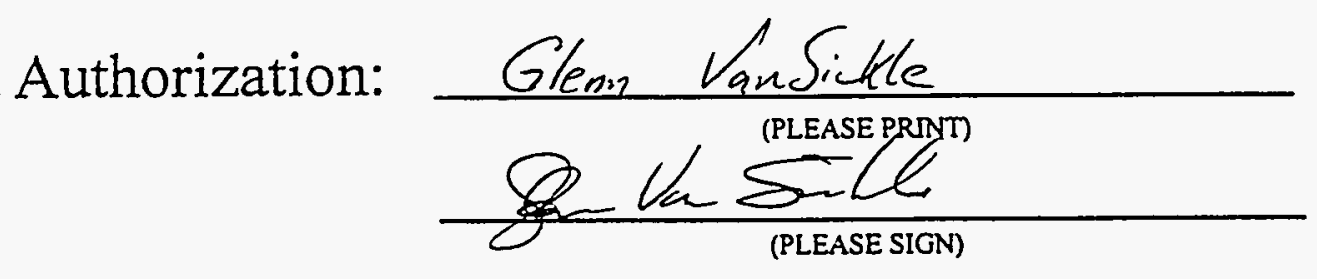


DOE/RL-96-19

Rev. 0

CONTENTS

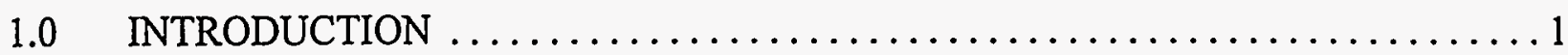

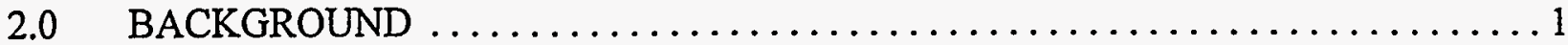

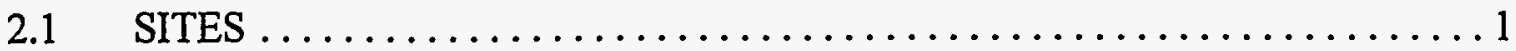

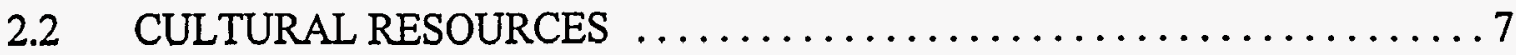

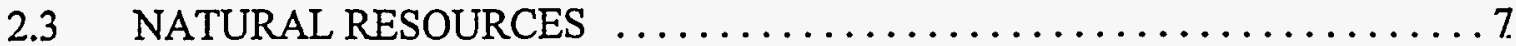

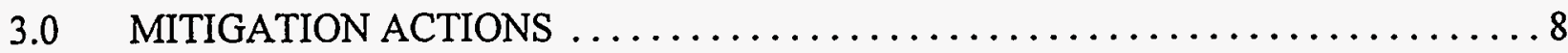

3.1 CULTURAL RESOURCE MITIGATION $\ldots \ldots \ldots \ldots \ldots \ldots \ldots \ldots \ldots$

3.2 NATURAL RESOURCE MITIGATION $\ldots \ldots \ldots \ldots \ldots \ldots \ldots \ldots$

3.3 POST-REMEDIATION SITE PREPARATION $\ldots \ldots \ldots \ldots \ldots \ldots \ldots \ldots$

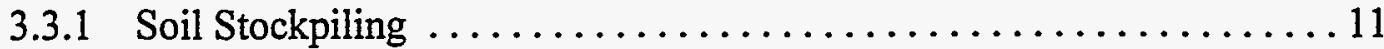

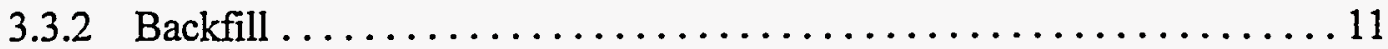

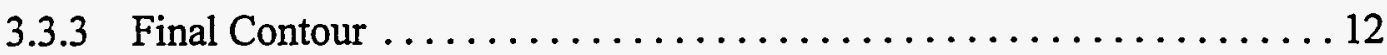

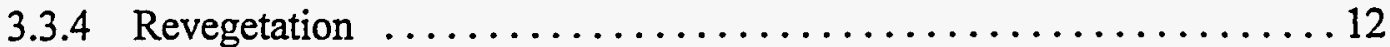

3.4 OTHER MITIGATION ACTIONS $\ldots \ldots \ldots \ldots \ldots \ldots \ldots \ldots \ldots \ldots \ldots \ldots \ldots \ldots$

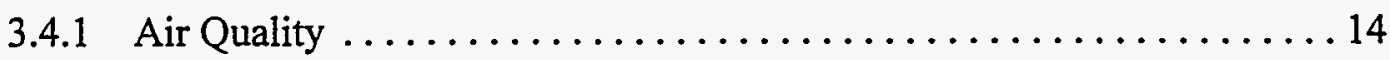

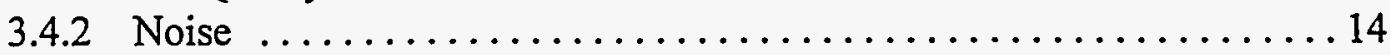

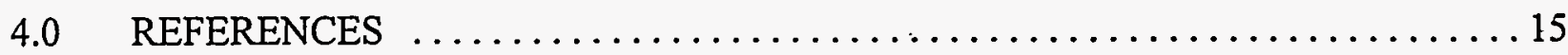

\section{FIGURES:}

1. Location of 100-BC-1 Waste Sites Addressed in this Report $\ldots \ldots \ldots \ldots \ldots \ldots \ldots$

2. Location of 100-DR-1 Waste Sites Addressed in this Report $\ldots \ldots \ldots \ldots \ldots \ldots \ldots$

3. Location of 100-HR-1 Waste Sites Addressed in this Report $\ldots \ldots \ldots \ldots \ldots \ldots \ldots 6$

4. Locations of Backfill Borrow Pits in the 100 Areas ..................... 13 
DOE/RL-96-19

- Rev. 0

\subsection{INTRODUCTION}

"It is Department of Energy policy to manage all of its land and facilities as valuable national resources. Our stewardship will be based on the principles of ecosystem management and sustainable development. We will integrate mission, economic, ecologic, social, and cultural factors in a comprehensive plan for each site that will guide land and facility use decisions. Each comprehensive plan will consider the site's larger regional context and be developed with stakeholder participation. This policy will result in land and facility uses that support the Department's critical missions, stimulate the economy, and protect the environment." (O'Leary 1994)

A Record of Decision (ROD) was issued for remediation of waste sites in the 100-BC-1, 100-DR-1, and 100-HR-1 Operable Units in the 100 Area of the Hanford Site. This Mitigation Action Plan (MAP) explains how mitigation measures for these remedial activities will be planned and implemented. The new activities planned in the ROD are not anticipated to result in releases of hazardous substances and will minimize disturbance of currently undisturbed areas. However, certain actions required by the ROD may result in the redisturbance of areas of recovering vegetation. This MAP presents a strategy for limiting disturbances and identifies an opportunity for revegetating a previously disturbed site; the knowledge gained from this demonstration project (Weiss 1996) can be applied to final revegetation of the rest of the remediated sites and sites disturbed during cleanup when remediation of an area is completed.

This work will be conducted in coordination with the Natural Resource Trustees Council and Native American Tribes to help minimize impacts to natural resources and cultural resources from project activities and to restore the remediated sites to an appropriate level of habitat.

\subsection{BACKGROUND}

This section describes the resources at the waste sites and support facilities that are expected to be affected. Most of the waste sites to be remediated are not currently vegetated, but some general mitigation measures should be taken at every site affected. Mitigation actions are described in Section 3.0.

\subsection{SITES}

This project involves the remediation of selected 100 Area waste sites (Figures 1 through 3). The following waste sites are affected. 
DOE/RL-96-19

Rev. 0

\begin{tabular}{|c|c|c|}
\hline Waste Site & Description & $\begin{array}{c}\text { Estimated } \\
\text { disturbed acreage }\end{array}$ \\
\hline \multicolumn{3}{|c|}{ Shown in Figure 1} \\
\hline $116-C-1$ & Process effluent trench & 3 \\
\hline $116-\mathrm{B}-1$ & Process effluent trench & 1 \\
\hline $116-C-5$ & Retention basin & 8 \\
\hline $116-\mathrm{B}-11$ & Retention basin & 8 \\
\hline $116-\mathrm{B}-12$ & Crib & $<1$ \\
\hline $116-B-5$ & Crib & $<1$ \\
\hline $116-\mathrm{B}-13$ & Sludge trench & $<1$ \\
\hline $116-B-14$ & Sludge trench & $<1$ \\
\hline $116-B-4$ & French drain & $<1$ \\
\hline $116-B-9$ & French drain & $<1$ \\
\hline $\begin{array}{l}\text { 100-B/C Buried process effluent } \\
\text { pipelines }\end{array}$ & & 6 \\
\hline $116-\mathrm{B}-2$ & Fuel storage basin trench & $<1$ \\
\hline $116-B-3$ & Pluto crib & $<1$ \\
\hline $116-B-6 A$ & Crib & $<1$ \\
\hline $116-B-6 B$ & Crib & $<1$ \\
\hline $116-\mathrm{B}-10$ & Dry well/quench tank & $<1$ \\
\hline $\begin{array}{l}\text { Material handling and container } \\
\text { transfer facility }\end{array}$ & & $2-4$ \\
\hline \multicolumn{3}{|c|}{ Shown in Figure 2} \\
\hline $116-D-1 A$ & Trench & $<1$ \\
\hline $116-D-1 B$ & Trench & $<1$ \\
\hline 116-D-7 & Retention basin & 3 \\
\hline 116-DR-9 & Retention basin & 4 \\
\hline 116-DR-1 & Process effluent trench & $<1$ \\
\hline
\end{tabular}


DOE/RL-96-19

Rev. 0

\begin{tabular}{|c|c|c|}
\hline Waste Site & Description . & $\begin{array}{c}\text { Estimated } \\
\text { disturbed acreage }\end{array}$ \\
\hline $116-\mathrm{DR}-2$ & Process effluent trench & $<1$ \\
\hline $116-\mathrm{D}-2 \mathrm{~A}$ & Crib & $<1$ \\
\hline $116-\mathrm{D}-4$ & Crib & $<1$ \\
\hline 116-D-9 & Crib & $<1$ \\
\hline $116-\mathrm{D}-6$ & French drain & $<1$ \\
\hline 107-D1 & Sludge trench & $<1$ \\
\hline 107-D2 & Sludge trench & $<1$ \\
\hline 107-D3 & Sludge trench & $<1$ \\
\hline 107-D4 & Sludge trench & $<1$ \\
\hline 107-D5 & Sludge trench & $<1$ \\
\hline $1607-\mathrm{D} 2$ & Septic system and tile field & $<1$ \\
\hline $\begin{array}{l}\text { 100-D/DR Buried process effluent } \\
\text { pipelines }\end{array}$ & & 4 \\
\hline $\begin{array}{l}\text { Material handling and container } \\
\text { transfer facility }\end{array}$ & & $2-4$ \\
\hline \multicolumn{3}{|c|}{ Shown in Figure 3} \\
\hline $116-\mathrm{H}-7$ & Retention basin & 5 \\
\hline $116-\mathrm{H}-1$ & Process effluent trench & 3 \\
\hline $116-\mathrm{H}-4$ & Pluto crib & $<1$ \\
\hline $116-\mathrm{H}-2$ & Effluent disposal trench & 2 \\
\hline $\begin{array}{l}\text { 100-H Buried process effluent } \\
\text { pipelines }\end{array}$ & & 3 \\
\hline $\begin{array}{l}\text { Material handling and container } \\
\text { transfer facility }\end{array}$ & & $2-4$ \\
\hline
\end{tabular}


Figure 1. Location of 100-BC-1 Waste Sites Addressed in this Report.

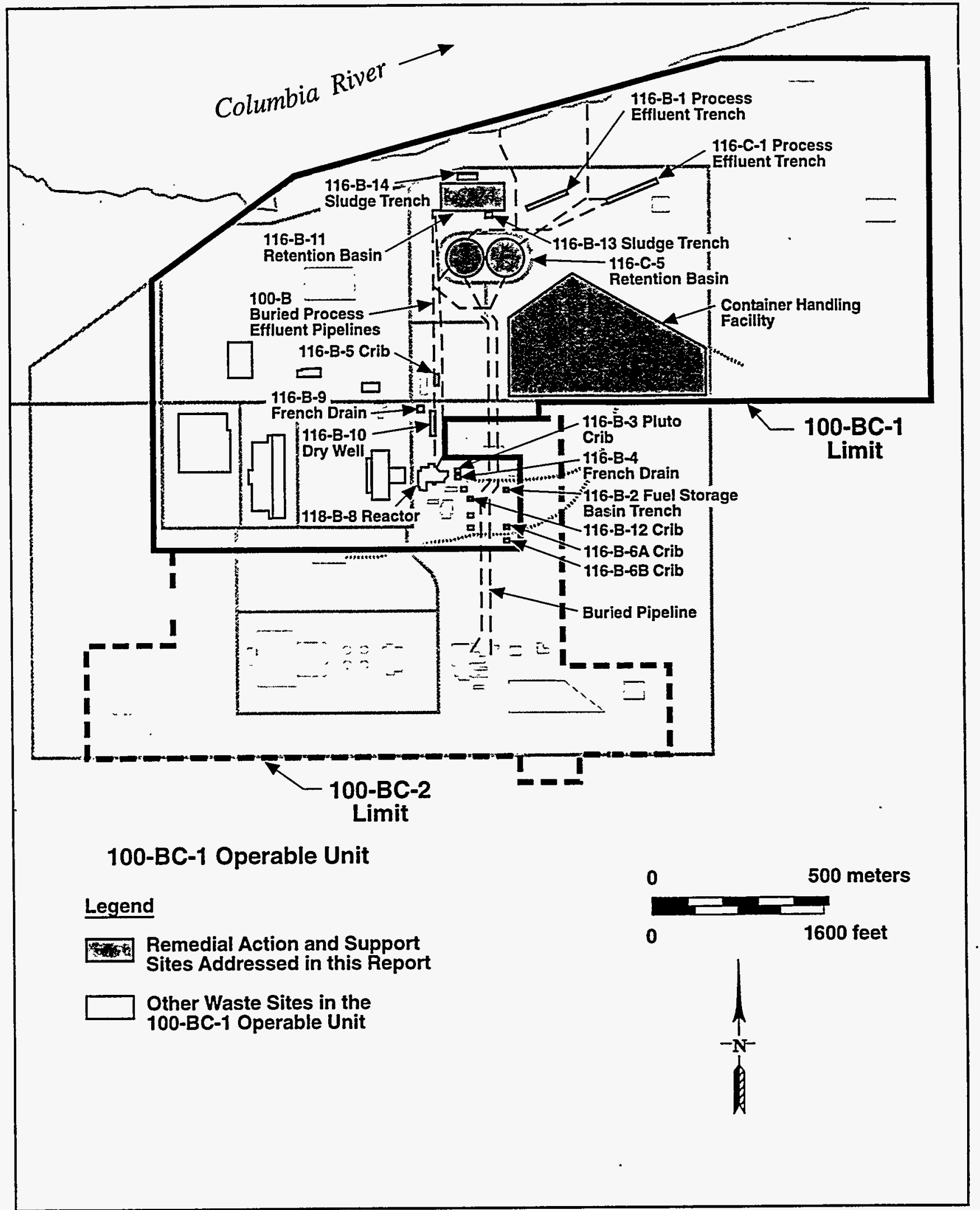




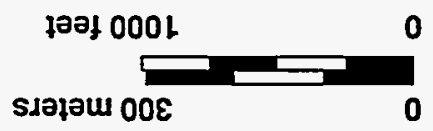

sy!un әाqesədo

z-4G-00L pue L-yG-00L

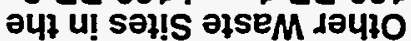

นodəy s!̣น u! passespp

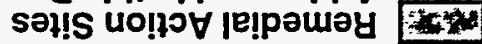

Sגə̧əu $00 \varepsilon$

$\mathbf{0}$

рนจ6ว7

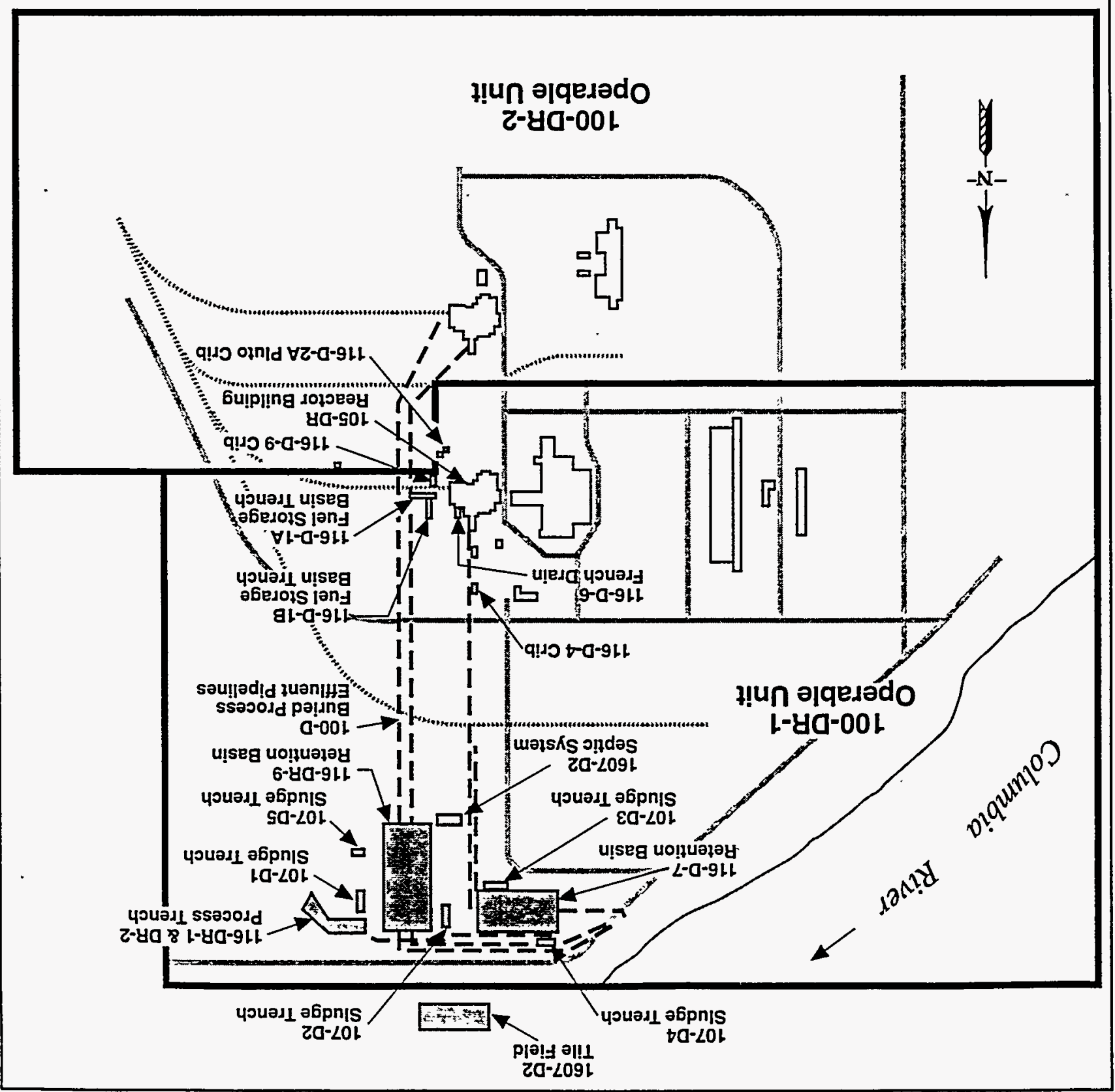

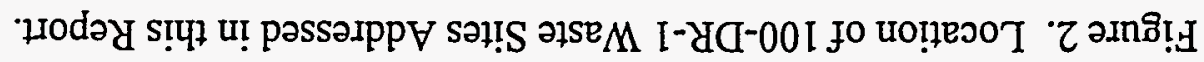


Figure 3. Location of 100-HR-1 Waste Sites Addressed in this Report.

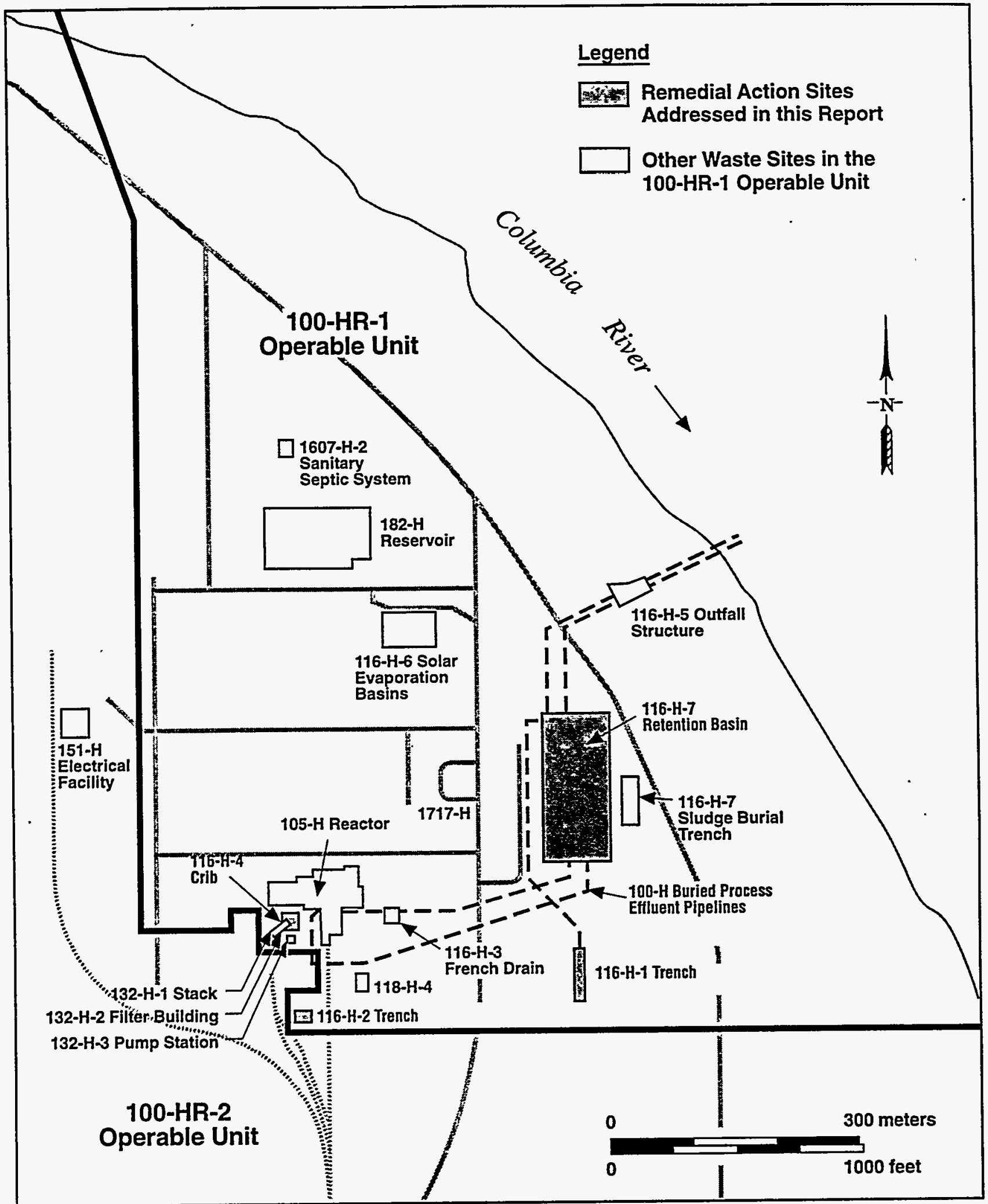

E9601026.1 
Rev. 0

One other site, the Container Handling Facility (Figure 1), is planned to be used for common support facilities in the 100-BC-1 Area. While the entire area as șown in Figure 1 will not be disturbed, the percentage that will be used is not yet known, nor are the precise locations of roads and facilities. Mitigation may also be undertaken at common support facilities at other reactor areas, site-specific support areas, and future borrow areas depending on the effects at these sites.

\subsection{CULTURAL RESOURCES}

The Columbia River corridor passing through the Hanford Site has always been important to humans. As a result, archaeological sites, human burials, traditional use areas, and historic buildings exist in the area. Any area within $400 \mathrm{~m}$ (1/4 mile) of the Columbia River that has not been extensively disturbed has a high probability of containing important cultural resources. Protection of these sites is required by Federal law.

\subsection{NATURAL RESOURCES}

Of these sites, only 116-C-1, 116-H-1, 1607-D2 Tile Field, and the Container Handling Facility (for loading and transferring excavated material) have any significant vegetation onsite or nearby that could be affected by removal actions. There is little or no surrounding vegetation at the other sites because of heavy past disturbance from construction and operation activities, and residual pre-emergent herbicides. Thus, natural resources are not expected to be adversely affected by remedial actions at those sites.

Site $116-C-1$ is devoid of vegetation, but is surrounded by areas with early successional-stage vegetation, such as cheatgrass (Bromus tectorum), tarweed fiddleneck (Amsinckia lycopsoides), bulbous bluegrass (Poa bulbosa), tumblemustard (Sysimbrium altissimum), rabbitbrush (Chrysothamnus nauseosus), and Sandberg's bluegrass (Poa sandbergii). These plants provide . generally low-quality habitat, mostly used during winter for grazing geese, deer, and rabbits. Some of these vegetated areas will need to be used for excavation support facilities such as trailers, parking areas, spoil piles, and transportation corridors.

Site 116-H-1 is devoid of vegetation over the first cell. However, areas posted as surface contamination continue to the south. Historical photographs show these areas as two additional cells that were subsequently backfilled. The surface of these areas is covered with early successional-stage vegetation such as cheatgrass and tumblemustard, which provide low-quality habitat. Disturbance of this vegetated area will be a result of excavation to remediate the subsurface; avoidance and minimization mitigation for these low-quality invader species will not be undertaken. 
Since it was constructed, about $50 \%$ of the approximately 0.5 -ha (1-acre $\left.{ }^{1}\right) 1607-D-2$ Tile Field has restored to sagebrush (Artemisia tridentata). However, in recent years much of the sagebrush near the D Area has died, including about $95 \%$ of the mature sagebrush over the tile field. While the causes for this die-off are not known, the spatial and temporal patterns of dead sagebrush suggests natural causes. Younger sagebrush are re-establishing over part of the area, with an understory dominated by cheatgrass, but also with Sandberg's bluegrass and other native and non-native species. Much of the land surrounding the tile field is still dominated by cheatgrass and tumblemustard.

The entire proposed Container Handling Facility site has been heavily disturbed in the past, but subsequently allowed to revegetate. The site vegetation is in a mosaic, with predominately cheatgrass and tumblemustard fields, but it also contains a large amount of rabbitbrush in patches. A smaller stand of sand dropseed (Sporobolus cryptandrus) is in the southeast corner of the site. No sagebrush appears to be present. Sandberg's bluegrass has recolonized the entire area, with densities lower where cheatgrass is the dominant plant and higher where rabbitbrush has recolonized. The transfer facilities will be enclosed in an area about 18 ha ( 45 acres); rabbitbrush patches are about $4 \mathrm{ha}(10$ acres) of that total. The area is bisected by a railroad and has many rock piles of various sizes (and many sizes of rocks). For cost, transportation, and contamination control reasons, this area has been proposed for the handling facility.

\subsection{MITIGATION ACTIONS}

Mitigation refers to a series of prioritized actions designed to minimize or lessen potential project impacts on cultural or natural resources. The first choice of mitigation is to avoid the impact entirely; for instance, the project can be moved away from significant habitat. Mitigation may also involve minimizing the impact, rectifying the impact afterwards, and/or compensating for significant impacts. The mitigation actions described below will be conducted to avoid or minimize the impacts to natural and cultural resources during remedial actions. Mitigation of undisturbed or colonized sagebrush areas will be addressed appropriately (e.g., to plan compensating mitigation of quality habitat areas that could not be avoided). However, such impacts are considered unlikely at this time. The following measures have been taken during project design and will continue to be taken as appropriate as planning continues and through operations.

${ }^{\prime}$ Most of the metric to English conversions are approximate because of the nature of the measurements provided. 


\subsection{CULTURAL RESOURCE MITIGATION}

Surface-disturbing and building-disturbing activities will be preceded by a Cultural Resource Review (CRR) and will comply with the recommendations resulting from that review. The CRR process will include the following.

- Research of the areas to be impacted to determine the likelihood that cultural resources exist. Field visits may be needed as part of the assessment, depending on factors such as the degree of previous disturbance, extent of previous field surveys in the area, and the likelihood that cultural resources are present. Discussions may be held with the State Historic Preservation Office and the Indian tribes and nations regarding the nature and extent of protective measures that may be needed.

- Written directions will be developed to implement the appropriate measures.

Recommendations might include the following, depending on the site.

- $\quad$ Project activities will be moved away from sensitive areas, or sensitive areas will otherwise be protected where possible (e.g., not scraping the ground surface when placing support facilities).

- Surface surveys and test excavations will be made, when needed, to determine the presence/absence of cultural resources.

- $\quad$ Project activities will be monitored to minimize disturbance to cultural resources.

- Mitigation measures such as archaeological excavations, human burial removal, or detailed building documentation will be conducted when adverse impacts to cultural resources cannot be avoided.

The State Historic Preservation Office and Native Americans will be notified prior to appropriate mitigation actions.

\subsection{NATURAL RESOURCE MITIGATION}

- Ecological surveys will be performed in project areas, before activities begin, to identify and avoid protected species.

- Encroachment (e.g., new roads, support facilities) into clean areas with native vegetation will be limited to the maximum extent feasible.

- Long-lasting herbicides will not be used to control unwanted vegetation near facilities in areas where the ground has not recently been sprayed with herbicide. This practice will help the areas to revegetate when the facilities are removed. 
- Prudent fire control practices will be exercised while minimizing the vegetation disturbances for firebreaks (especially in years with heavy growths of cheatgrass and other weeds that could rapidly carry wildfire to areas with sagebrush). Plant communities dominated by perennial grasses and shrubs are more resistant to wildfires than areas dominated by annuals such as tumbleweed and cheatgrass.

- Control access to the river during remediation of near-river sites through administrative practices. (The rivershore provides habitat for large numbers of wildlife). For example, where appropriate, light, temporary fencing will serve to limit both casual access and control any blowing trash.

- Backfill materials should come from previously undisturbed vegetated areas only as a last resort.

The following site-specific mitigation measures will also be undertaken.

- If the 1607-D-2 Tile Field is to be remediated, remove the small sagebrush plants and transplant them to a nearby area to provide seed sources in places currently lacking sagebrush. This action should be done in fall or winter after the seasonal precipitation has begun and the soils are moist. If needed, additional water can be added to the planting holes.

- Limit the area disturbed for the Container Handling Facility to the minimum necessary. All areas disturbed for these support facilities will be replanted with both native grasses and sagebrush (both sagebrush seeds and tubelings). This replanting will occur when the support facilities are removed. Replanting will not wait until the rest of the 100-BC Area is ready for revegetation. However, because these facilities will be used for an estimated 5 to 10 years, a detailed revegetation plan is not presented here. The methods used will depend on the results of the 116-C-1 revegetation and other vegetation projects.

- Demonstrate, on an area that will not receive further disturbance, methods of revegetating with native species remediated waste sites in the 100 Areas. The 116-C-1 site has been chosen for this demonstration project (see Weiss 1996).

\subsection{POST-REMEDIATION SITE PREPARATION}

While active revegetation efforts will be conducted in the near-term only at the 116-C-1 site, other steps must be taken to complete the cleanup and backfill phase of remediation at the other sites. Issues such as backfill soil, site contour, and herbicides must be addressed now to allow engineers to complete their designs and avoid precluding likely future revegetation work. The items below address these issues. 
Rev. 0

\subsubsection{Soil Stockpiling}

It is anticipated that most sites will have approximately $1.5 \mathrm{~m}(5 \mathrm{ft})$ of clean overburden. During waste site remediation, the clean surface of soils that have not been treated with a long-lasting herbicide will be stockpiled at a nearby location and associated vegetative material will be incorporated. It is best to use these stockpiled soils within 2 years to ensure the viability of mycorrhizae (soil microorganisms that many native plant species depend on). The stockpiled soils may need to be covered with a crusting agent (e.g., polymer) to keep the wind from eroding . them.

\subsubsection{Backfill}

The aim of site restoration is to have the remediated sites and sites disturbed during remedial activities eventually return to a shrub-steppe community with a minimum of non-native species. However, the revegetation part of each site's post-cleanup restoration may need to be delayed to allow for future activities such as cleanup of nearby waste sites and final decisions on future land use. Thus, the final cleanup stages of restoration should allow for the most efficient future revegetation.

Unfortunately, final methods for revegetating the large remediated areas have not yet been developed. The structure of soils (e.g., percentages of sand, loam, amount of organic material) will play an important part in final revegetation. It is also probable that areas surrounding each remediated waste site will not be revegetated with intensive methods (e.g., importing large amounts of soil). Generally, the best interim backfill is to approximate the soil structure found in the top $1 \mathrm{~m}(3 \mathrm{ft})$ of the surrounding nonremediated area. This soil structure varies to a limited degree but, in general, the soils in these areas are disturbed and tend to be silty, sandy, gravels with boulders (e.g., DOE-RL 1992). Most of this land will eventually support vegetation if long-lasting herbicides are no longer applied and the sites are given time to lose the remaining herbicides. Thus, ensuring the soil on the remediated sites approximates the surrounding soil will avoid a "patchwork" appearance to these areas as the sites revegetate.

Deeper (below 3-4 $\mathrm{m}$ [9-12 ft]) backfill soils can be of very low quality. Coal ash, boulders, concrete rubble, etc., can provide deeper backfill and can probably be used in part for the higher layers (1-3 m [3-9 ft]) when mixed with mineral soils of other structural sizes. Some roots will penetrate at least to $3 \mathrm{~m}(9 \mathrm{ft})$, so the soils to this depth should provide some suitable structure (some fines in the voids). In addition, to minimize the potential for contact by roots, soils that are known to have been recently treated with long-lasting herbicides should not be placed within $3 \mathrm{~m}(10 \mathrm{ft})$ of the surface, unless analysis shows the soil to be suitable.

At this point, the issue of importing large quantities of fine-structured topsoil to the remediated reactor areas has not been decided. Important considerations will be the effects of such actions on the borrow sites and transportation corridors and the costs and benefits of such action. However, as active revegetation efforts begin on a larger scale for the reactor areas, it may be 
decided that from to $30 \mathrm{~cm}$ to $1 \mathrm{~m}$ ( 1 to $3 \mathrm{ft}$ ) of topsoil is needed for successful revegetation. If so, deeper backfill for the holes from the last of the remediated sites can be scraped from the surface of the surrounding areas. Then, imported topsoil for the entire area can be spread more . evenly across the larger site.

Additional soil compaction is not necessary at this time. Through the course of backfilling, the movement of heavy equipment on the surface should provide the limited compaction needed for revegetation.

Several sources of backfill exist. The order of preference is to (1) stockpile and reuse clean soil from the remediated site, (2) use backfill from nearby mounds left over from earlier facility construction, (3) use ash from remaining ash piles, (4) use materials from existing borrow areas and, as a last resort, (5) use backfill from new borrow areas. Existing borrow locations in the 100 Areas are shown in Figure 4. Backfill removal that involves disturbing overburden or topsoil will need an excavation permit. If spoil piles that have naturally revegetated will be used for backfill, the topsoil will be saved and used as topsoil in final restoration and the site of the spoil pile will be revegetated.

Ideally, excavating topsoil material at the borrow site should not cause the loss of vegetation or it should impact only very low-quality habitat such as cheatgrass fields. However, careful consideration should be given when borrowing topsoils from sites that support stands of only or predominantly cheatgrass because their suitability for restoring native vegetation may not be good. (Some soils at Hanford appear to be much better at naturally revegetating to native species than others, while some, such as the old fields in the 100 Areas and parts of the McGee Ranch, remain virtually all cheatgrass after 50 years.)

\subsubsection{Final Contour}

The final contour of the remediated sites should reflect the surrounding terrain to the extent practical. For most of the area, this will be approximately to grade, which is essentially flat to very gently sloping. For example, grade for sites 116-B-1, 116-B-11, 116-B-13, and 116-B-14 is approximately $132.5 \mathrm{~m}$ above sea level, and grade for site $116-\mathrm{C}-5$ is about $133.5 \mathrm{~m}$. It should be noted that the quantity of backfill required to bring all remediated 100 Area waste sites back to an essentially flat contour will be significant. The benefits of restoring such a contour will have to be weighed against the potentially significant impacts to borrow sites.

\subsubsection{Revegetation}

Active revegetation at this time is limited to the 116-C-1 site (see Weiss 1996), because sites closer to the reactor areas will be in the process of remediation or will be potentially affected by future remediation, for many more years. In the meantime, issues such as the best methods for revegetation of large areas, future land use, use of imported soils, depths, and amendments, and 


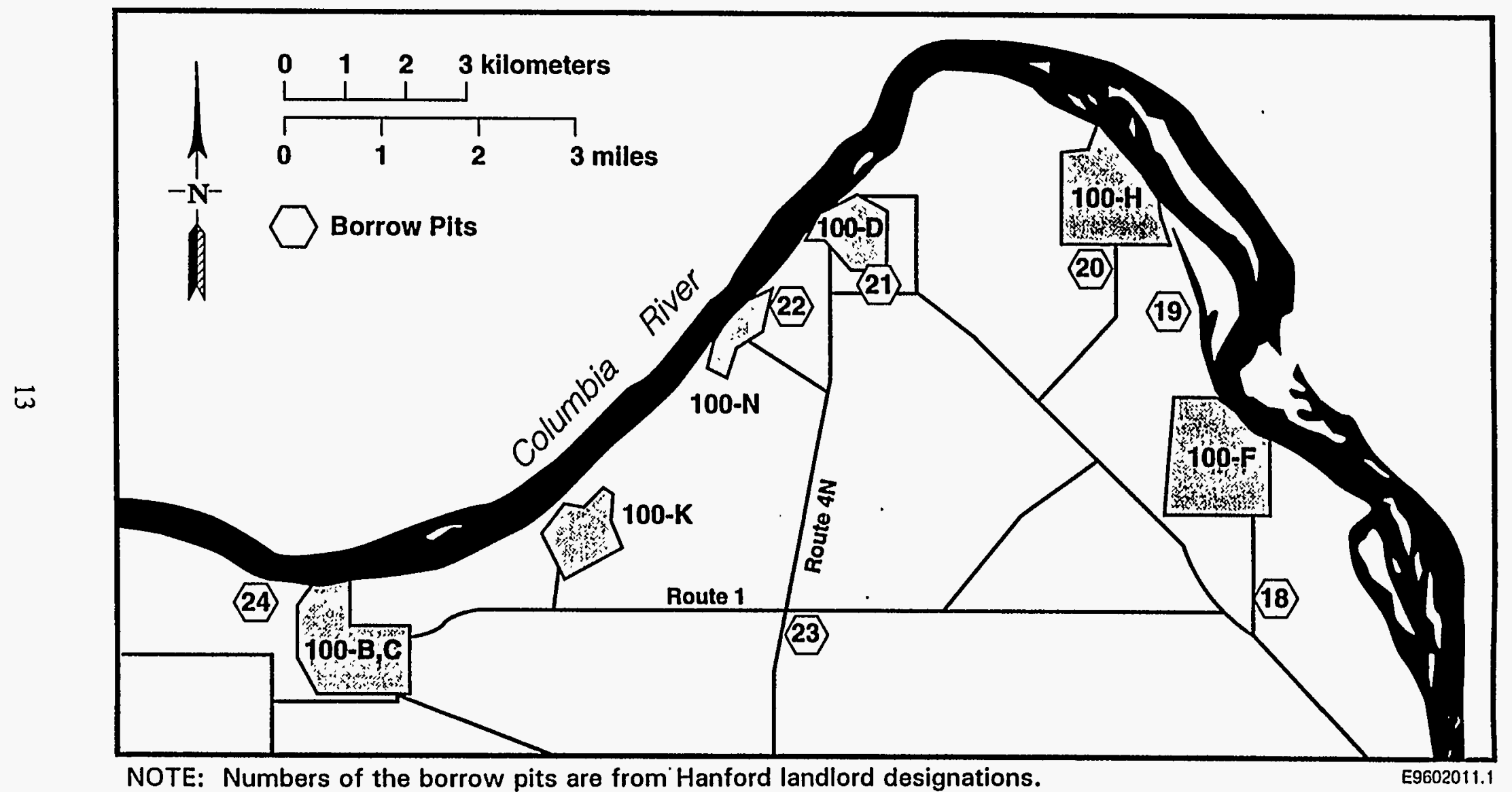


Rev. 0

soil preparation in areas adjacent to remediated sites need to be addressed, and the residual herbicides can be allowed to degrade. Revegetation plans will be developed for interim site stabilization and final revegetation on all sites. Final large-scale revegetation may be delayed until large remediated areas are no longer being disturbed and the results of additional information gathered from the 116-C-1 revegetation work, revegetation manual (in preparation), and other sources can be incorporated to help ensure success. In addition, the Container Handling Facility and 1607-D Tile Field will be revegetated when this project is completed in several more years, rather than waiting for the final complete remediation of the entire reactor areas. Their revegetation plans will be based on the results of the 116-C-1 revegetation and other current information.

After remediation is completed and before reseeding has begun, weeds will have the opportunity to invade the site. These weeds could have a deleterious effect on the survival of native species that will be seeded later. Thus, on sites that will not be actively revegetated with native species within 12 months of backfilling, it is preferable to seed with a grass such as crested wheatgrass (Agropyron cristatum) to help control weed invasion.

\subsection{OTHER MITIGATION ACTIONS}

\subsubsection{Air Quality}

Preservation of air quality will require specific mitigation actions during remedial activities because of the dry, relatively windy climate at Hanford. Dust control will be a vital component to prevent the potential spread of contamination from exposed soils. Dust will be controlled by water spraying or other approved methods. A crusting agent or fixant will be applied to any disturbed portion of the contamination area that will be inactive for more than 24 hours. Dust control will be maintained at all times, including when excavation or other work activities are not occurring. Controlled locations include, but are not limited to, the limits of waste site excavations, access ramps, roads, parking areas, the Container Transfer Facility, and stockpiles.

\subsubsection{Noise}

Remedial activities will generate noise, primarily through the use of heavy earthmoving and transport equipment. Noise impacts will be highest inside the sites being remediated, with secondary effects along the roads. Because the most significant noise will be confined to the immediate project site and access areas, it is unlikely to significantly affect the environment. 
Rev. 0

\subsection{REFERENCES}

DOE-RL, 1992, Remedial Investigation/Feasibility Study Work Plan for the 100-BC-1 Operable Unit, Hanford Site, Washington, DOE/RL-90-07, Rev. 0, U.S. Department of Energy, Richland, Operations Office, Richland, Washington.

O'Leary, H. R., 1994, "Land and Facility Use Policy," Memorandum from H. R. O'Leary, Secretary of Energy, to Secretarial Officers and Operations Office Managers, dated December 21, 1994, U.S. Department of Energy, Washington, D.C.

Weiss, S. G., 1996, Revegetation Plan for the 116-C-1 Site, BHI-00628, Rev. 0, Bechtel Hanford, Inc., Richland, Washington. 


\section{DISTRIBUTION}

Number of Copies

QNSITE

22 U.S. Department of Energy Richland Operations Office

D. C. Ward

N. A. Werdel (20)

A5-55

J. H. Zeisloft

$\mathrm{H} 0-12$

HO-12

26

ERC Team

R. L. Donahoe

$\mathrm{H} 0-17$

V. R. Dronen

$\mathrm{H} 0-17$

G. R. Eidam

$\mathrm{HO}-17$

K. A. Gano

$\mathrm{HO}-02$

C. J. Kemp

$\mathrm{HO}-02$

A. L. Langstaff

$\mathrm{HO}-17$

T. D. LeFrancois

H9-03

K. R. Myers

$\mathrm{X} 0-17$

M. J. Ostrom

H9-03

L. Pamplin

$\mathrm{HO}-18$

F. V. Roeck

$\mathrm{HO}-04$

D. D. Teel

$\mathrm{HO}-02$

M. C. Tyler

H9-03

G. E. VanSickle

$\mathrm{HO}-17$

S. G. Weiss (7)

H9-03

BHI Document Control (3)

H0-09

Hanford Technical Library

P\&-55

Public Reading Room

H2-53

Distr-1 